\title{
ICONOGRAFÍA DE LOS FRONTISPICIOS DE LAS COLECCIONES COSTUMBRISTAS DE TIPOS SOCIALES EN EUROPA Y LATINOAMÉRICA
}

\author{
Dorde Cuvardic García
}

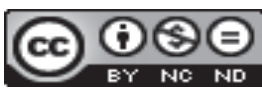

Esta obra está bajo una licencia Creative Commons

Reconocimiento-No Comercial-Sin Obra Derivada 



\title{
ICONOGRAFÍA DE LOS FRONTISPICIOS DE LAS COLECCIONES COSTUMBRISTAS DE TIPOS SOCIALES EN EUROPA Y LATINOAMÉRICA
}

\section{ICONOGRAPHY OF THE FRONTISPIECES IN THE COSTUMBRIST COLLECTIONS OF SOCIAL TYPES IN EUROPE AND LATIN AMERICA}

\section{Dorde Cuvardic García}

\begin{abstract}
RESUMEN
En este artículo se realiza un análisis iconográfico de los frontispicios de las más importantes colecciones costumbristas de tipos sociales en Europa y América Latina. Desde una intencionalidad metafórica, se muestran espectáculos ópticos (la linterna mágica y el tutilimundi) u objetos relacionados con su exhibición ante un público, representativo de la Nación (el lienzo donde se proyectan las imágenes de las sesiones de linterna mágica). Se busca expresar con estas analogías que las colecciones de tipos sociales, al igual que estos espectáculos, ofrecen al público los más diversos tipos sociales. Además, también se ha identificado en este artículo la analogía de la colección costumbrista con la práctica de la pintura, el dibujo y la caricatura. Afiches publicitarios observados por un público representan otra situación iconográfica reconocible en los frontispicios costumbristas. Al recurrir a las analogías mencionadas, los proyectos editoriales de las colecciones de tipos sociales quieren destacar que estas últimas son prácticas significantes tanto verbales como visuales.
\end{abstract}

Palabras clave: frontispicios, costumbrismo, linterna mágica, tutilimundi, ilustración.

\begin{abstract}
In this article an iconographic analysis of frontispieces of the most important costumbrist collections of social types from Europe and Latin America is carried out. With a metaphoric intention, optical entertainment devices (magic lantern and tutilimundi) from the XIX century visual culture, along with objects related to their display (such as the magic lantern canvass where images are projected) are considered. 'El diablo cojuelo' ('The crippled devil'), a satirical symbol, and the audience are also incorporated in this early frontispiece modes. This iconography used in costumbrist collections, as well as optical shows, offer to the audience a gallery of representative national social types. Moreover, in other frontispieces the analogy of costumbrist collections has also been identified with the significant practices of painting, drawing, and caricature. Finally, advertisement posters observed by an audience also represent another typical iconographic situation of costumbrist frontispieces. Resorting to analogies, the publishing projects of social types collections use for its representation verbal as well as visual practices.
\end{abstract}

Key words: frontispieces, literature of customs and manners (costumbrism), magic lantern, tutilimundi, illustration.

Dr. Dorde Cuvardic García. Universidad de Costa Rica. Profesor de la Escuela de Filología, Lingüística y Literatura. Costa Rica.

Correo electrónico: dcuvardic@yahoo.es

Recepción: 04- 03- 2013

Aceptación: 24- 05- 2013 


\section{Introducción}

El frontispicio, la ilustración de la 'portada interna' del libro, fue utilizado masivamente en la práctica editorial occidental hasta inicios del siglo XX. ${ }^{1}$ Su estudio pertenece al campo de investigación de las relaciones texto-imagen en la literatura. En su función de paratexto o programador de lectura, supone una excelente manifestación, a nivel visual, de los objetivos y de la visión de mundo de los editores del libro en el que se inserta.

Uno de los casos de frontispicios más conocidos -analizados sobre todo en la crítica académica francesa, alemana y anglosajona-, es el de las colecciones costumbristas de tipos sociales, en boga en Occidente entre 1830 y 1860. En el desarrollo del presente artículo tenemos como objetivo analizar, comparativamente, los frontispicios de las colecciones de tipos sociales de Europa Occidental y Latinoamérica, con el propósito de demostrar que el costumbrismo visual, a nivel internacional, empleó similares símbolos iconográficos en su preparación. En el pasado han sido analizados frontispicios franceses, alemanes, austriacos e ingleses (Lauster, 2007; Ucelay, 1951, p. 87), pero sin propósitos comparativos. Peñas-Ruiz (2012), en su inventario de la literatura panorámica española (compilaciones de escenas, colecciones de tipos sociales, fisiologías) los incorpora en su artículo, como medio ilustrativo, pero no analiza iconográficamente su contenido.

Para conocer la propuesta estética e ideológica en los frontispicios de las colecciones costumbristas europeas y latinoamericanas de tipo sociales aplicaremos el método iconológico. Como es ampliamente conocido (utilizado en la lectura de cuadros, murales, grabados, fotografías, etc.), será suficiente con ofrecer un resumen. Mediante su aplicación, el analista trata de identificar historias, alegorías y figuras o personajes -análisis iconográfico- a partir de la identificación de los objetos que estos últimos manipulan y de las situaciones que protagonizan -descripción pre-iconográfica-. Por último, estas historias, alegorías o figuras o imágenes se interpretan a partir del contexto filosófico, ideológico o estético en el que surgieron -en lo que se conoce como interpretación iconológica (Panofski, 1983)-.

Nuestro corpus está formado por los frontispicios de las siguientes colecciones de tipos sociales europeas y americanas: Heads of the people; or, Portraits of the English, (edición de 1840 y de 1864); Los franceses pintados por sí mismos (Les Français peints par eux-mêmes), Vols. I, III y IV (1840-1842), París o El libro del ciento y uno (1831-4), El diablo en París (1845-46) y Los belgas pintados por sí mismos (1839). En el ámbito español, analizaremos Los españoles pintados por sí mismos, Vols. I (1843) y II (1844), Los niños pintados por ellos [sic] mismos (1841) y Doce españoles de brocha gorda (1846), y en el latinoamericano, Los cubanos pintados por sí mismos (1852) y de Los mexicanos pintados por sí mismos (1854).

En primer lugar, nos ocuparemos de analizar los frontispicios que comparan la escritura costumbrista con la pintura, el dibujo y la caricatura, como principio analógico principal, mientras que, seguidamente, nos dedicaremos a analizar los frontispicios que utilizan, como principio básico, los dispositivos ópticos de la cultura popular en boga a mediados del siglo XIX, sobre todo -aunque no sólo- la linterna mágica.

\section{La analogía pictórica y el dibujo en los frontispicios costumbristas}

En correspondencia con la recurrente analogía establecida en la "Introducción" y en numerosos artículos de Los españoles pintados por sí mismos entre la descripción y la pintura de tipos sociales (algo muy común en el costumbrismo internacional), el frontispicio del 


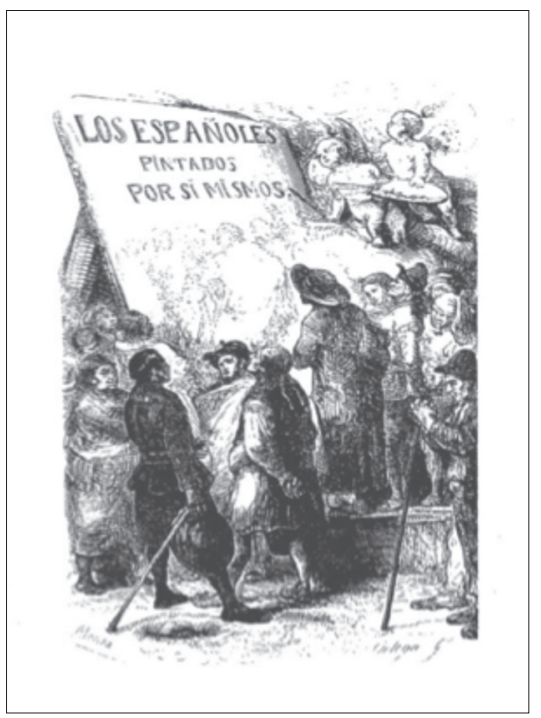

Imagen 1. Léonardo Alenza (Dibujo). Calixto Ortega (Grabado). (1844). Los españoles pintados por sí mismos. Vol II.
Volumen II de esta colección se encarga de visualizar esta equiparación (Imagen 1). Representa en términos literales la metáfora costumbrista de la 'pintura' -descripción- de tipos sociales. Aunque por su textura también podría ser una tabla de madera, podemos afirmar que este frontispicio muestra un enorme lienzo, que a su vez ofrece una imagen con figuras humanas y, en su parte superior, una leyenda con el título de la colección. Su gran tamaño alude a la magnitud de esta empresa editorial (que cuenta con alrededor de cien tipos sociales). En otras palabras, se encuentra representado, bajo el procedimiento de la puesta en abismo, un imaginario frontispicio de 'Los españoles pintados por sí mismos', desde el formato de la pintura. El 'frontispicio pintado' parece estar terminado: ningún pintor maneja un pincel frente a la imagen. Los querubines, que llevan en la mano izquierda la paleta de colores y en la derecha el pincel, no cumplen el papel de creadores artísticos. Simplemente es una alegoría que persigue el objetivo de reforzar la metáfora pictórica del costumbrismo, en el marco del malinterpretado verso horaciano 'la poesía -la literatura- debe ser como la pintura'. ${ }^{2}$ Con curiosidad, diversos tipos sociales españoles están observando esta traducción pictórica del frontispicio. El público, como veremos en algunos de los próximos ejemplos, es típico de este tipo de imágenes.

La analogía pictórica también se utiliza en el frontispicio del Tomo IV de la colección Los franceses pintados por sí mismos (1840) (Imagen 2). Diversos tipos sociales se encuentran ubicados alrededor de un cuadro sin enmarcar, donde aparece el título. Este lienzo recientemente ha sido descubierto: la manta que lo cubría ha sido doblada hacia atrás. El individuo que fuma, con el brazo derecho apoyado sobre la parte superior del cuadro sin enmarcar, parece ser el editor de la colección (Léon Curmer), satisfecho $-\mathrm{y}$ autosuficiente- por el trabajo realizado, la colección de tipos sociales que ha patrocinado, simbolizada por el lienzo. Una selección de tipos del Tomo IV parece estar representada en este frontispicio: el diplomático, por el busto ubicado frente al cuadro (se satiriza su aire de grandeza y su pretensión de 'pasar a la posteridad'); los niños de París, a quienes se dedica un artículo colectivo, por la niña que, sentada en un almohadón, dispone distintas postales de los 'Gritos de París', ${ }^{3}$ a los que se dedica, por su parte, otro artículo en este volumen, en forma de castillo de naipes; el vendedor de 'coco' (popular bebida hecha de regaliz macerado y agua con limón), por el sujeto que, en segundo plano, detrás del dibujante, aparece con una gran garrafa sobre

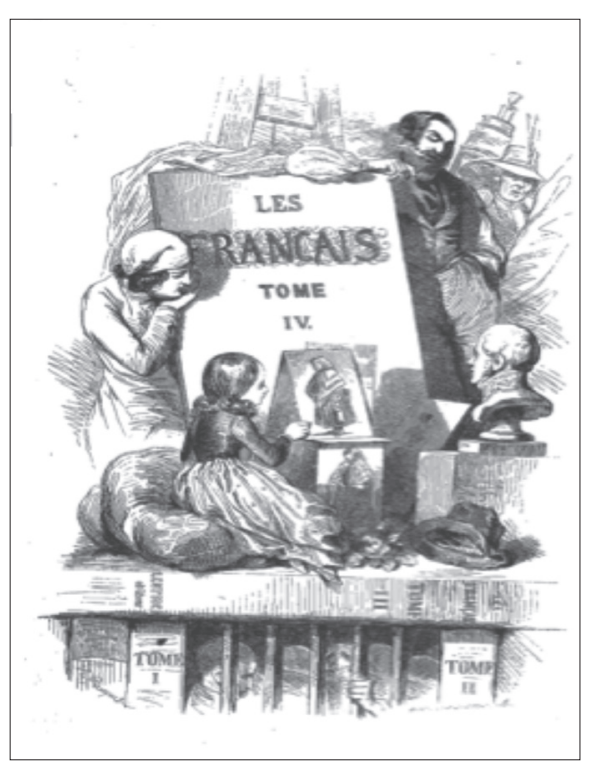

Imagen 2. Pauquet (Dibujo). Firma ilegible (Grabado). (1840). Los franceses pintados por sí mismos. Vol. IV. 
sus espaldas; los pobres, a los que se dedica también un artículo, parecen estar simbolizados por el sombrero arrugado y envejecido que se encuentra en el suelo; el 'segundo marido' -objeto de otro artículo- parece ser el sujeto vestido en pijama que se apoya sobre el cuadro sin enmarcar; los presos, que también tienen asignado un texto, aparecen en el frontispicio debajo de los tipos descritos previamente, para significar la posición baja que ocupan en la escala social, en una celda con barrotes cuyo techo y paredes consisten en los primeros tres tomos de Los franceses pintados por sí mismos.

La descripción de tipos sociales desde la analogía del retrato caricaturesco se representa en el frontispicio del Volumen I de Heads of the People 4 (1840) (Imagen 3), dibujado por Kenny Meadows. Es una ilustración de claro tono satírico. En el centro, este dibujante se autorretrata como frenólogo en el proceso de confeccionar una caricatura. Mide la anchura del cráneo de una niña que berrea, a su izquierda, mientras observan sus complacidos padres, a la derecha del dibujante. Detrás, diversos tipos sociales como el alguacil o bedel de la parroquia (con el sombrero napoleónico) o el deshollinador esperan su turno para ser dibujados. Destaca Lauster (2007, p. 87) que, agrupados como están detrás del dibujante frenólogo, se muestran como un 'cuerpo social', desde la idea de colectivo nacional; además, representan a tipos sociales que cuentan con su respectivo artículo en la colección (con lo que esta muestra representa a una totalidad). El hecho de que la escena quede encuadrada por una puerta -que alude al marco de los cuadros y de los grabados- sugiere,

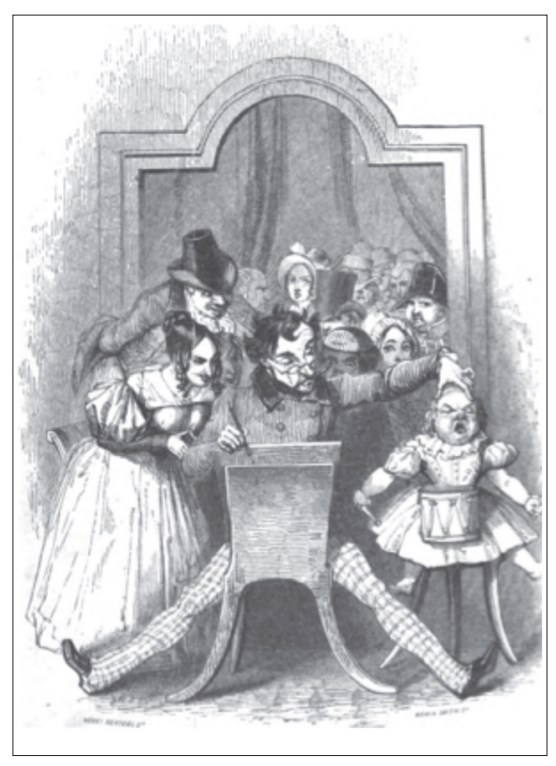

Imagen 3. Kenny Meadows (Dibujo). Orrin Smith (Grabado). (1840). Heads of the People.

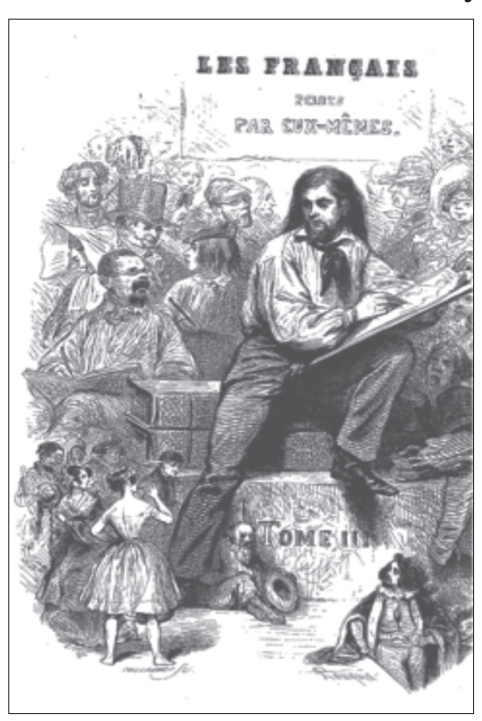

Imagen 4. Pauquet (Dibujo), Guillaumot (Grabado). (1840). Los franceses pintados por sí mismos. Vol. III. según Lauster (2007, p. 87), que todos estos tipos terminarán por quedar enmarcados en una representación visual. ¿Qué motiva al dibujante frenólogo a involucrarse en una producción 'industrial', en serie, dedicada a los tipos sociales y qué incita a estos últimos, de manera entusiasta, a ser representados, por el primero?, se pregunta Lauster (2007, p. 87), e inmediatamente ofrece la siguiente respuesta: le puede motivar la necesidad económica, ya que no dispone de caballete y debe usar, por contrapartida, el respaldar de la silla, así como el deseo de pasar a la posteridad como un dibujante 'científico', caracterizado por la precisión (cobran relevancia sus anteojos, además de sus dotes frenológicas); a los tipos sociales del público, por su parte, les puede motivar la participación en una práctica de moda, el retrato frenológico, y la necesidad de quedar retratada su fisonomía rápidamente, antes de que cambien con el paso del tiempo (como en el caso de la niña).

El frontispicio del Tomo III de Los franceses pintados por sí mismos (Imagen 4) guarda similitudes con el frontispicio de Heads of the people. Ambos representan el momento del 
proceso creativo, del caricaturista-frenólogo, en el caso inglés, y del dibujante, en el francés. Debajo del afiche publicitario de la colección, donde se inserta el título de este frontispicio, se muestra al dibujante en pleno desempeño, con una hoja sobre tabla apoyada sobre el muslo izquierdo, rodeado de tipos sociales que pueden remitir tanto a sus creaciones (las figuras representadas, el resultado de su trabajo) como a los modelos de los que se sirve para elaborar sus dibujos, a los tipos sociales que se encuentran en su cerebro, listos para ser ejecutados en su cuaderno.

La gestualidad que adopta permite inferir que está realizando bocetos, croquis, términos que, recordemos, también se utilizan para designar los textos cortos del costumbrismo (escenas, artículos de tipos sociales). Aunque las figuras no se encuentran rodeadas de una nube, indicador claro de su carácter ilusorio (se utiliza, por ejemplo, para identificar el sueño que tiene un personaje), claramente se comprende que, organizadas alrededor del dibujante, no forman parte de su mismo espacio existencial. ${ }^{5}$ Pululan en el suelo y a la izquierda y derecha del dibujante. Se trata de un esquema compositivo muy típico del siglo XIX, que podemos llamar "el artista o escritor y sus creaciones o criaturas'. Sigue este esquema la conocida pintura inacabada "El sueño de Dickens" (1875), de Robert William Buss, donde diferentes escenas procedentes de las novelas del autor se singularizan en nubes independientes sobre su cabeza.

La asociación de la descripción costumbrista de los tipos sociales con la tradición del dibujo y el grabado (en suma, con la tradición impresa) se manifiesta al inicio del Volumen II de Heads of the people, en su edición de 1864 (Imagen 5). En la ilustración de la página del título, el utensilio del grabador, el buril, aparece en el centro de la portada interna de este volumen anudado junto a un grupo de plumas de dibujo. Se establece una relación

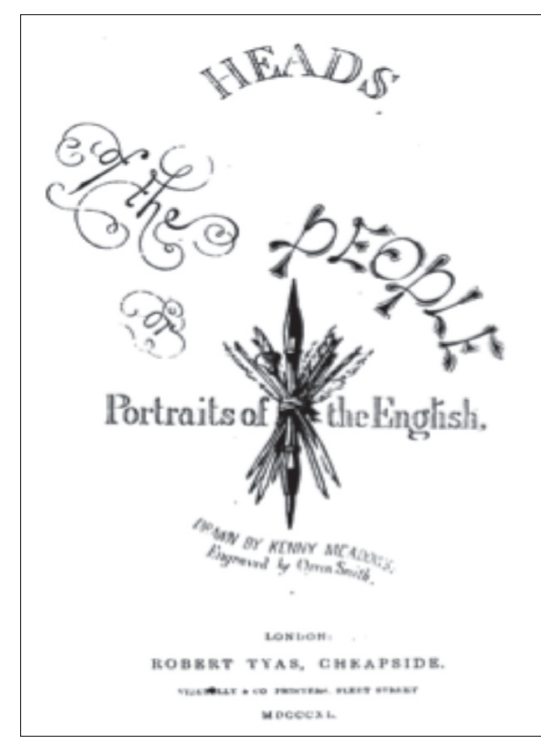

Imagen 5. Kenny Meadows (Dibujo). Orrin Smith (Grabado). (1940). Heads of the People.

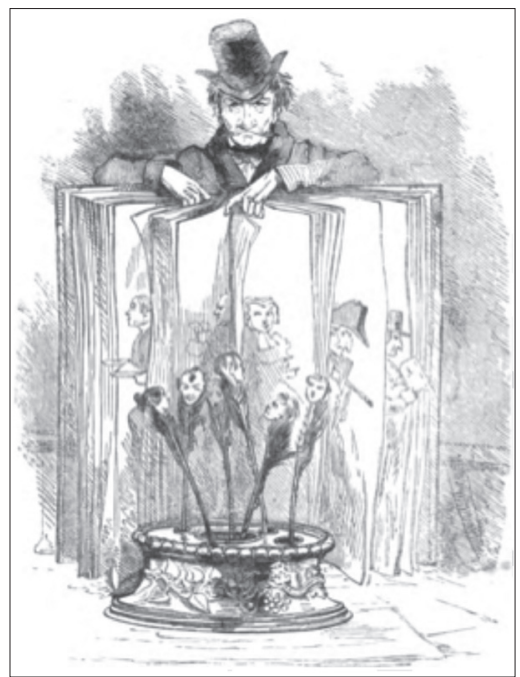

Imagen 6. Kenny Meadows (Dibujo). Orrin Smith (Grabado). (1864). Heads of the People. Vol II. metonímica de continuidad entre estos instrumentos y el título de la colección, ya que las distintas palabras de este último ('Heads of the People') aparecen en tipografía variada, realizada con estos medios, la pluma y el estilete. Algunas de las palabras del título, como ocurre con 'of', 'the' y 'or' -en sus respectivas letras- aparecen prolongadas con arabescos. Las palabras confeccionadas con una tipografía que se asemeja al estilo manuscrito (alejado de los clisés de la imprenta) remiten a una autoría artística alejada de los moldes fijos de la impresión mecánica, autoría que supuestamente dominará en los artículos y bustos o retratos de medio cuerpo del discurso visual de la colección.

En el frontispicio del Volumen II de Heads of the People, en la edición de 1864 (Imagen 6), Kenny Meadows se autorretrata detrás un gran libro ilustrado entreabierto, que representa a la colección en la que se inserta. Se trata de la misma colección de la que es frontispicio, en una 
puesta en abismo. Algunas de las ilustraciones dibujadas cobran vida: en el momento mismo de tomar movimiento, comienzan a caminar y abandonar las páginas. Sólo se aprecia el busto de los tipos sociales: no se ejecutan retratos de cuerpo entero en las láminas o estampas en página independiente de esta colección. Frente al libro se encuentra un tintero, donde están ubicadas algunas plumas. De la parte superior penden las cabezas de algunos tipos sociales representados en la colección. Metonímicamente se infiere que los retratos de medio cuerpo o bustos de los artículos han sido confeccionados con su pluma, símbolo de su maestría artística. Su trabajo ha terminado hace poco: Todavía sostiene entre los labios una de las plumas utilizadas en la elaboración de las ilustraciones. Asimismo, el resto de la plumas han sido depositadas en el tintero, después ser utilizadas.

El frontispicio de Doce españoles de brocha gorda (1846) (Imagen 7) ofrece algunos de los recursos que acabamos de analizar. Con el de la segunda parte de Los españoles pintados por sí mismos (1844) comparte el hecho de la presencia de un gran cuadro sin enmarcar, en este caso de piedra. 'De brocha gorda' puede tener diversos significados. Se puede referir a la técnica descriptiva utilizada por la colección costumbrista: en este caso, significaría 'apenas esbozados'. También puede aludir al referente representado: la unidad fraseológica, en este caso, designaría tipos sociales bastos, de ínfima categoría social, como el haragán, el granuja o el ignorante, a los que se dedican artículos en esta última colección. El tercer significado nos enfrentaría ante un típico caso de autodeprecación del discurso costumbrista, en este caso a nivel visual. Recordemos que este recurso se utiliza mucho en los artículos verbales, donde es común que se designe el texto como 'articulejo'. Mediante este tipo de designación, el escritor costumbrista realiza una crítica sobre su propia inserción en una escritura altamente mercantilizada como es la costumbrista (los artículos o sketches se vendían primero por suscripción y, posteriormente, en volúmenes). Creo que, en el presente caso, este recurso se traslada al frontispicio. ¿Qué iconografía permite expresar la autodeprecación? El hecho de que un niño -que ostenta la semántica de la falta de habilidad- esculpa en piedra el título de la colección con un cincel y un mazo (y ya no

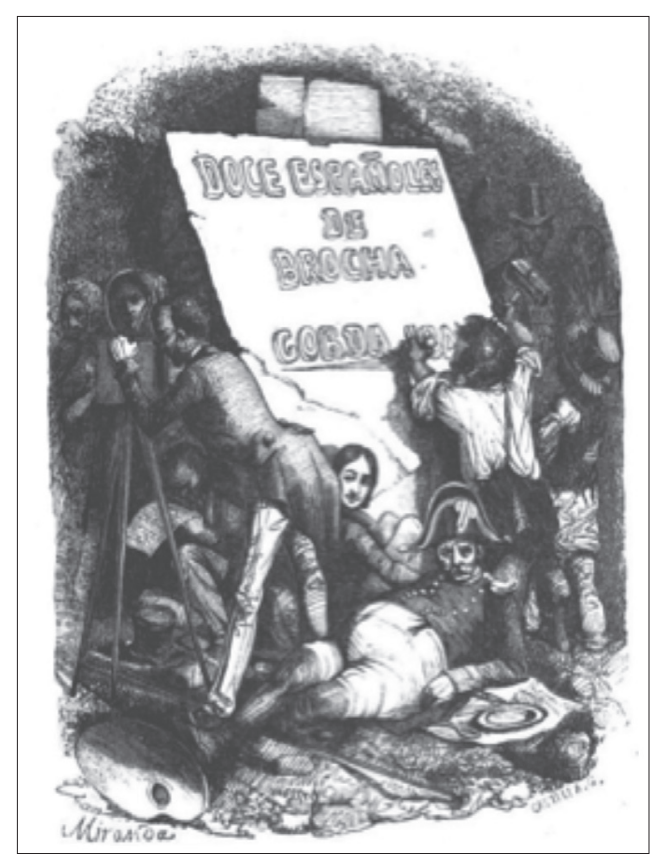

Imagen 7. Fernando de Miranda (dibujo). Castilla A.G. (Grabado). (1846). Doce españoles de brocha gorda.

propiamente con una brocha gorda). Además, es una parodia de las lápidas representadas en los frontispicios de los libros publicados durante el Clasicismo (Renacimiento y Barroco), donde se escribía el título de los libros. Con este procedimiento -que alude a las lápidas de las esculturas y monumentos de la Antigüedad-se pretendía otorgar una condición canónica -el valor de obra inmortal- a los textos que introducían.

Como sucede en casi todos los frontispicios de las colecciones costumbristas, el público de Doce españoles de brocha gorda se encuentra indiferente frente al desempeño del niño. Es posible que sea una alusión de la pobreza de su habilidad, que no merecería la 
atención de los espectadores. De este frontispicio también destaca la asociación de la escritura costumbrista con el daguerrotipo (un sujeto aparece manipulando el aparato), a un lado de la lápida de piedra, en detrimento de la analogía con la pintura, depreciada en este caso con la acción de 'pintar en piedra con un cincel y un mazo'. En la "Introducción" de Doce españoles de brocha gorda son numerosas las asociaciones con esta última tecnología, la fotografía, y ya no con la linterna mágica, algo que comparte con la "Introducción" de Los españoles pintados por sí mismos en la edición de 1851. Creo que la emergencia de la fotografía se vincula con la 'pretensión' de imparcialidad que 'exhiben' -que se autoatribuyen- los escritores costumbristas. De la ubicación de la paleta del pintor en el suelo, en un rincón, debajo del trípode del aparato fotográfico, se puede inferir el 'rebajamiento' de la metáfora de la pintura, y la correspondiente emergencia de la fotografía, a la hora de aludir a la intencionalidad de la escritura costumbrista como copia 'detallada', y ya no idealizada (ofrecer la Belleza 'universal'), de la realidad. Algunos tipos sociales parecen encontrarse a la espera de ser fotografiados.

En esta primera parte del presente artículo, nos queda por analizar un último frontispicio. La colección de tipos infantiles Los niños pintados por sí mismos (Les enfants peints par euxmêmes) (1841) tuvo dos adaptaciones en España y México bajo el título Los niños pintados por ellos [sic] mismos. La española es una traducción y adaptación realizada por Manuel Benito Aguirre en 1841, del original francés, escrito por Alexandre de Saillet. Por su parte, la edición mexicana, de 1843, es una adaptación, a su vez, del proyecto español. ${ }^{6}$ El frontispicio de la traducción española (Imagen 8) es, en realidad, un 'calco' del procedente de la edición original francesa del mismo año. Se eliminó la firma del dibujante y del grabador y se sustituyó el título original en el mismo espacio de la pared. En correspondencia con la semántica del título de la colección (infantes que se describen a sí mismos en los artículos, aunque es una ficción, ya que la autoría procede de un adulto), un niño subido a un poyo de piedra escribe el título en una pared. Se alude indirectamente a la idea de los garabatos dibujados por manos infantiles en las paredes (por este motivo, no pinta sobre un bastidor o sobre un caballete). No se aprecia bien en el calco español, pero en el original francés se distingue bien cómo el niño se agarra a los resquicios dejados por los ladrillos de la pared, con la ayuda de su mano izquierda. Una niña trata de sostener a su amigo por detrás, y otra se convierte en la única espectadora intradiegética de la escena. Este grupo se encuentra rodeado de otros niños. El mono vestido designa el mundo infantil de los juegos, mientras que los uniformes y las carteras del niño y de la niña que le sostiene alude a la esfera educativa. En la esfera lúdica y la escolar se proyecta visualmente la propuesta didáctica ofrecida en el contenido de este libro.

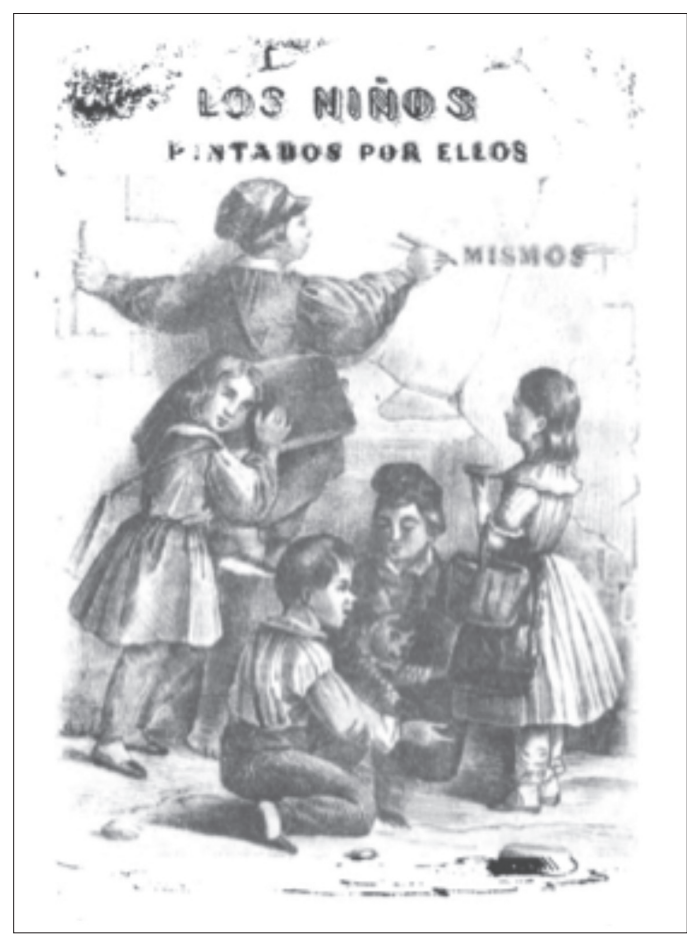

Imagen 8. Los niños pintados por ellos [sic] mismos (Copia anónima del original francés. (1841). Les enfants peints par eux-mêmes. 


\section{La analogía de la linterna mágica y el tutilimundi en los frontispicios costumbristas}

El lienzo, soporte para la inscripción del título de las colecciones costumbristas, no sólo supone la visualización de una de las principales metáforas utilizadas por estos proyectos editoriales, la de la pintura, sino también de otra importante analogía: el espectáculo de linterna mágica.

El frontispicio del Volumen I de "Los españoles pintados por sí mismos" (Imagen 9) muestra diversos tipos representativos de la Nación española, aunque sólo aquellos que miran en perfil o en mirada frontal pueden ser identificados por el analista, como ocurre con la maja, que mira directamente al lector, y con el chico de la calle. Los tipos sociales se encuentran agrupados alrededor de un lienzo que tiene inscritas las palabras "Los españoles pintados por sí mismos". Su soporte parece consistir en tres travesaños, dos verticales y uno horizontal. Un hombre, desde lo alto de este último, ayuda a desplegarlo.

El frontispicio de este primer volumen de la colección española, como se puede apreciar, utiliza la convención compositiva del lienzo desplegado ante un grupo de espectadores, empleada tanto en frontispicios de las colecciones costumbristas europeas (Los belgas pintados por sí mismos) como latinoamericanas (Los mexicanos pintados por sí mismos). Sin ser concluyente con la siguiente afirmación, considero que este lienzo, en la colección española, posiblemente remita a la superficie donde se proyectaría una sesión de linterna mágica, circunstancia que admite una lectura autorreflexiva del proyecto editorial costumbrista: la preparación del lienzo de proyección 'es' como el frontispicio de un libro, preparativo para la lectura. Tanto el frontispicio como el lienzo son el preámbulo de prácticas de visualización de tipos sociales (proyectados, en el caso de la sesión de la linterna mágica, o mostrados, en el caso de las ilustraciones de las colecciones costumbristas). Aunque la

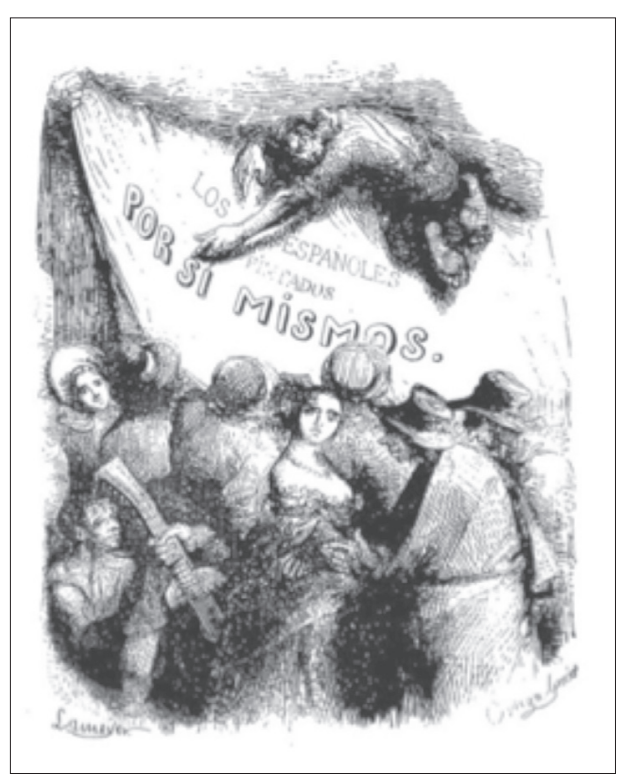

Imagen 9. Lameyer y Beranguer (Dibujo). (1873). Los españoles pintados por sí mismos. Vol I.

cercanía del encuadre no permita establecer ninguna afirmación concluyente, el sombreado de la parte superior parece indicar que la situación mostrada es nocturna y callejera. Recordemos que las proyecciones de linterna mágica no sólo se realizaban en el interior de los edificios, sino también en el exterior urbano en horas de la noche. Podría ser factible una interpretación alternativa: este lienzo es el telón de una función teatral callejera de tono costumbrista que representará la diversidad de tipos sociales españoles. En este caso, se estaría utilizando una metáfora dramática, teatral, en el frontispicio. Pero más allá del telón y del grupo de espectadores, nada más nos indica el circuito de la comunicación teatral, mientras que la hipótesis de la sesión de la linterna mágica queda reforzada por la situación mostrada, muy semejante a la de otros frontispicios, sobre los que ya ha sido establecida la analogía con este dispositivo óptico. Por otra parte, tampoco se alude al contexto pictórico: aunque el contexto 
situacional no es muy claro, el lienzo no parece pertenecer a una pintura ya terminada -sin enmarcar- de grandes dimensiones.

El frontispicio de Los mexicanos pintados por sí mismos (Imagen 10) también remite a la preparación de una sesión de linterna mágica. Mientras que Pérez-Salas (2005, p. 299) se limita a señalar que un grupo de personas rodean una manta desplegada, y llega a reconocer en esta situación una composición típica de los frontispicios de las colecciones europeas, sin dar más explicaciones, Segre (2007, p. 44) da una interpretación más precisa a la función revestida por el lienzo, al considerar que remite a las pantallas de los espectáculos de linterna mágica. Al igual que en el frontispicio del Volumen II de Los españoles pintados por sí mismos, es muy plausible esta interpretación. $\mathrm{Si}$ bien contamos con bastantes ilustraciones que muestran proyecciones realizadas directamente sobre una pared, como se visualiza en un aguafuerte de Augustin Zenger, ${ }^{7}$ de la primera mitad del siglo XVIII, o en un aguafuerte de Jonas Friedrich Clemens, ${ }^{8}$ de 1780 , en otros casos se proyectaban sobre el soporte de un lienzo, fijo en una pared, para dar mayor nitidez a la imagen proyectada, como ocurre en La linterna mágica (The Magic Lantern) (1823), aguafuerte y acuarela de S.W. Fores, ${ }^{9}$ o en el óleo sobre tela del pintor belga Jan Anton Garemyn (1712-1799), donde parece estar clavado sobre el techo de madera de una vivienda popular. ${ }^{10}$ Los lienzos representados en estas pinturas, así como el desplegado ante el público en Los belgas pintados por sí mismos

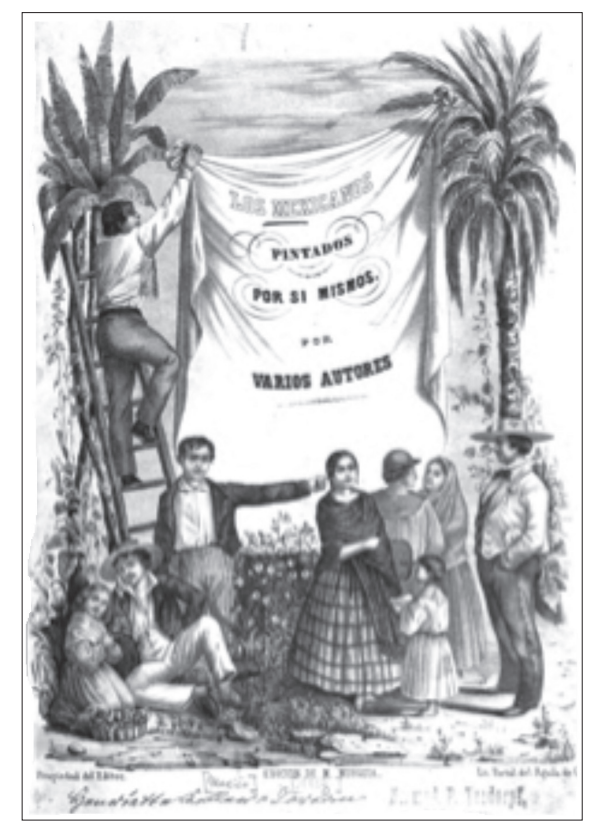

Imagen 10. Dibujante anónimo. (1854). Los mexicanos pintados por sí mismos.

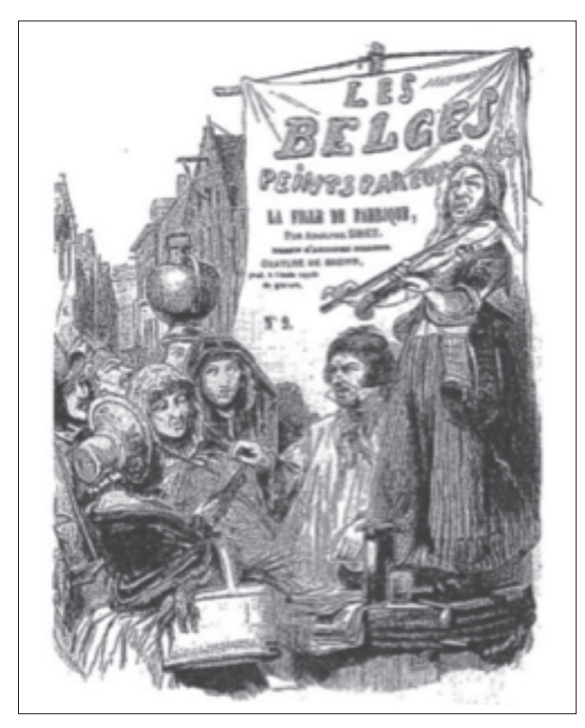

Imagen 11. Adolphe Dillens (dibujo). Brown (grabado). (1840). 'La fille du fabrique", Les belges peint par eux-mêmes. En: Le Men (1993).

(Imagen 11), tienen dimensiones similares al mostrado en el frontispicio de Los mexicanos pintados por sí mismos, que utiliza dos ramas como soporte para fijar sus extremos superiores y desplegarlo verticalmente. El lienzo de la colección belga parece estar sostenido en una especie de trípode (bajo un formato de exhibición parecido al de las actuales sesiones de diapositivas). La identificación con una sesión de la linterna mágica no sólo queda favorecida por la manta, sino también por la presencia de una mujer que toca el violín, ya que estos espectáculos contaban con el apoyo de la música como reclamo para llamar la atención del público. En este último frontispicio, podemos afirmar que el maestro de ceremonias entrega hojas pertenecientes al género de los Gritos que, como ya se dijo, son precursores de los proyectos editoriales costumbristas, hojas individuales de venta en pregón que ofrecían la representación visual de un tipo social callejero, junco 
con su identificación y un pequeño comentario. Al prestar atención al reparto de las hojas, el público no observa el lienzo, como sí ocurre, en cambio, en el frontispicio del Volumen II de Los españoles pintados por sí mismos. El lienzo del espectáculo de la linterna mágica aparece convertido en una especie de 'portada' del proyecto costumbrista belga. Se podría establecer una última hipótesis, que permitiría interpretar el lienzo que tiene incorporado el título de la colección como un simple afiche publicitario, ofrecido a los espectadores, -ya no en soporte de papel, sobre una pared-, sino de tela. Pero al carecer de pruebas sobre la existencia de afiches de tela a mediados del siglo XIX, no podemos respaldar, por el momento, esta última hipótesis.

Si regresamos al frontispicio de Los mexicanos pintados por sí mismos, observaremos que un público, no muy numeroso, se concentra ante el lienzo en espera del inicio de la sesión de linterna mágica. ¿Qué tipos sociales representa? Algunos de los que aparecerán proyectados (el pueblo se reconoce a sí mismo en los sujetos representados), e integrados, además, en las páginas de la colección costumbrista. Segre (2007, p. 44) ve a una china, tipo social que tiene su respectivo artículo. Por su parte, Pérez-Salas (2005, p. 301), además de identificar a esta última, también distingue a un aguador y a un ranchero, que también aparecen representados en el proyecto editorial. Al aguador, personaje de espaldas, se le reconoce sobre todo por su visera, que forma parte de la iconografía de los que practicaban esta actividad en México. Son tipos sociales exclusivamente mexicanos (china) o variantes locales de tipos universales (el ranchero y el aguador) señalados mediante el gesto indicativo del dedo extendido por un personaje que se encuentra al pie de la escalera. Es posible que muestre a un maestro de ceremonias del espectáculo de linterna mágica, pero este personaje también podría representar, como personaje singularizado, a la colectividad de escritores y de ilustradores que se encuentra detrás del proyecto editorial. A pesar de su gesto indicativo, y del potencial centro de atracción que supone, en principio, el lienzo desplegado, los tipos sociales mostrados aparecen conversando entre sí o en actitud de espera.

Lo autóctono, en este frontispicio, no sólo lo ofrece la muestra representativa de tipos sociales locales. También se encuentra otorgado por la presencia de vegetación autóctona: se puede distinguir una mata o árbol de plátano, a la izquierda (en cuyo tronco se encuentra apoyada la escalera por la que sube un sujeto, que terminará de anudar el lienzo en una de sus ramas), y una palmera, en una de cuyas hojas ya ha sido anudada la otra esquina. Es, más que todo, una concesión a la iconografía exótica con la que, supuestamente, debería contar el frontispicio de toda colección costumbrista americana.

Como acabamos de señalar, la exhibición visual de tipos (el contenido representado) sería la similitud iconográfica que, en principio, permitiría establecer analogías visuales, en los frontispicios analizados, entre los espectáculos de linterna mágica y las colecciones costumbristas de tipos sociales. Si se piensa que los frontispicios emplean el espectáculo de la linterna mágica como una alusión metafórica a las páginas internas de las colecciones costumbristas donde quedarán impresos verbal y visualmente los tipos sociales (de la misma forma que en el lienzo se visualizan las vistas y tipos proyectados por la linterna mágica) queda eliminada la incongruencia de pensar que las proyecciones de estos espectáculos fueran nocturnas, mientras que los lienzos ofrecidos en los frontispicios de Los mexicanos pintados por sí mismos y de Los belgas pintados por sí mismos se encuentran desplegados a plena luz del día, en una ubicación exterior. ${ }^{11}$ Asimismo, la excentricidad -y dificultad- de anudar un lienzo a una palmera y a una mata de plátano en el frontispicio de la colección mexicana potencia esta lectura analógica. 
Cuando se recurre metafóricamente a las sesiones de linterna mágica en los frontispicios de las colecciones costumbristas, no siempre aparece el lienzo donde se proyecta este espectáculo. En los conocidos frontispicios París, o El libro del ciento y uno (1831-4) y en El diablo en París (1845-6), se visualiza el instrumento de proyección, el aparato de linterna mágica, en lugar del momento de su recepción (con el lienzo desplegado ante los espectadores).

En el frontispicio de París, o el libro del ciento y uno (Paris, ou Le libre des cent-etun) (1831-1834), de Henry Monnier (dibujante) y Charles Thompson (grabador) (Imagen 12), Diógenes -delante del tonel en el que vive-sostiene una pequeña linterna mágica. Es una alusión a la lámpara que llevaba este filósofo griego en las calles de Atenas a plena luz del día: empleaba este objeto en el marco de su sátira social. Cuando los transeúntes le preguntaban sobre este extraño comportamiento, contestaba que buscaba a un verdadero hombre, libre de corrupción, en una época en la que esta última dominaba la esfera pública de la ciudad. En el frontispicio de la colección, la lámpara de Diógenes queda resignificada como linterna mágica. Con ello, se quiere decir que todo aquel lector que encare la lectura París, o el libro del ciento y uno encontrará una galería de imágenes, como las que se aprecian en las sesiones de este dispositivo óptico, donde las costumbres serán objeto de sátira correctiva o moralista. Además, el Diablo Cojuelo o Asmodeo (identificado por su pequeño tamaño, su pata de palo y su muleta), símbolo de la sátira moral para el costumbrismo, se encuentra subido a un tonel. Lleva puesta la caperuza del bufón, de tres picos -y un cascabel al término de cada uno de ellos-, típica de esta figura. Con su incorporación se quiere reforzar el espíritu satírico de la colección, desde la alegoría del Diablo Cojuelo. Lauster (2007, pp. 164168) ha destacado que la figura bufonesca, que también remite al tópico del mundo como teatro (o el teatro del mundo), no sólo se encuentra en el frontispicio que nos ocupa, sino también en la portada de otros proyectos editoriales, como ocurre en el primer y el quinto volumen del famoso semanario satírico inglés Punch

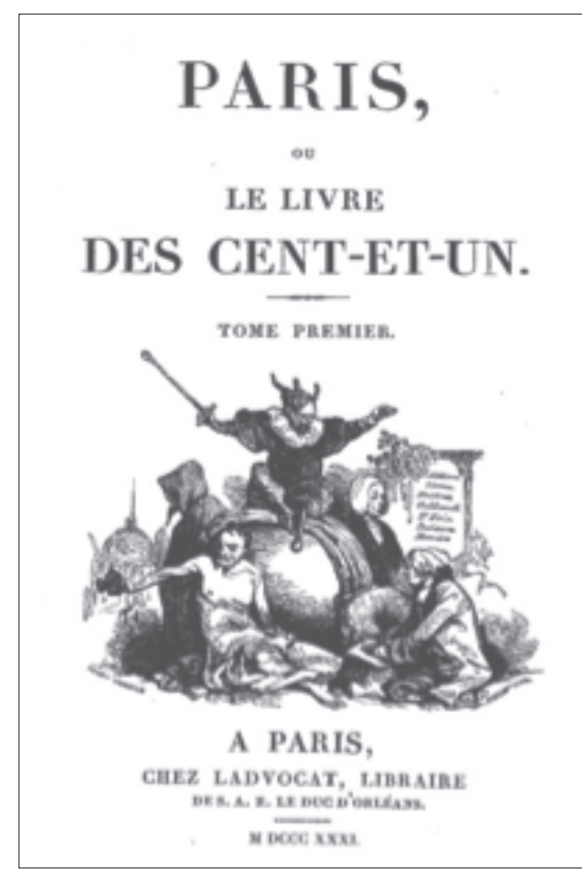

Imagen 12. Henry Monnier (Dibujo); Charles Thompson (Grabado). (1831)Ilustración de la página del título de Paris, ou Le Livre des Cents-et-un. Vol. I. (título que deriva de Polichinela) (1843) y en la sobreportada de la colección Viena y los vieneses (1844). También se encuentra en el "Prólogo" de El diablo en París la ilustración de un diablo con la típica caperuza del bufón.

Al estar sentado el Diablo Cojuelo sobre un tonel no sólo se quiere indicar su condición de heredero del espíritu crítico de Diógenes. También se quiere destacar que, al encontrarse en un lugar elevado, observa panorámicamente (desde una 'visión de conjunto') las costumbres sociales, como asimismo lo hacen las propias colecciones costumbristas. Un ermitaño se encuentra de espaldas al tonel, una alusión a Victor-Joseph Étienne de Jouy, conocido bajo el pseudónimo El eremita de la casa de Antin, en la colección de escenas urbanas del mismo título, publicadas en 1814. Una inscripción, en segundo plano y a la derecha, muestra una lista de famosos satíricos del siglo XVIII. La escritura costumbrista de París o el libro del ciento y 
uno queda, en este sentido, enraizada en una tradición prestigiosa: Joseph Addison (iniciador de la prensa burguesa satírica con The Spectator -1712- junto con Richard Steele), Lawrence Sterne (autor de Las aventuras de Tristan Shandy), Henry Fielding (autor del Tom Jones), Oliver Goldsmith (conocido por su obra satírica, El ciudadano del mundo), Sainte-Foix (sin duda, se trata de Germain-François Poullain de Saint-Foix, autor de comedias y de Cartas de un turco en París -1730- a imitación de las Cartas persas de Montesquieu) Dulaure (JacquesAntoine Dulaure, historiador del siglo XVIII) y Louis-Sébastien Mercier (el precedente más inmediato de la tradición del tableau, cuadro o escena costumbrista). Lauster (2007, p. 134) considera que Joseph Addison es, sin duda, el personaje que toma notas y que observa esta escena, debajo de la lista del nombre de estos últimos escritores.

En el frontispicio de la colección El diablo en París (1845-1846) (Imagen 13), dibujado por Gavarni, Flammèche -procedente del infierno, como se explica en el "Prólogo"-, un Diablo cojuelo adaptado al contexto decimonónico (pierde su cojera, pero mantiene su actitud observadora, escudriñadora, con vestimenta típica de un $d a n d y)$, adopta un motivo clásico del trapero: el cesto lleno de papeles. Recuérdese que la cultura decimonónica estableció la alegoría del periodista como trapero: de la misma forma que en el saco o cesto del recolector de trapos y papeles viejos todo queda nivelado (las 'cimas' de la literatura están al lado de escritos de ínfima calidad), igualmente en las páginas del periódico todo queda igualado: cultura con deportes, obituario con política... La muerte también nivela todo, en referencia a las distinciones de clase, de ahí la utilidad satírica del trapero. En el frontispicio de El diablo en París, los escritos del cesto, desordenados, designan la condición miscelánea, sin férrea clasificación, de cada uno de los textos de la colección. Este dandy sostiene un bastón, pero la curvatura de la empuñadura también lo asemeja a una pequeña guadaña, símbolo de la muerte, que todo lo nivela, al igual que la colección presta la misma importancia a tipos de distinta condición social. Se encuentra sobre un mapa de París (una representación cultural) que escudriña con su

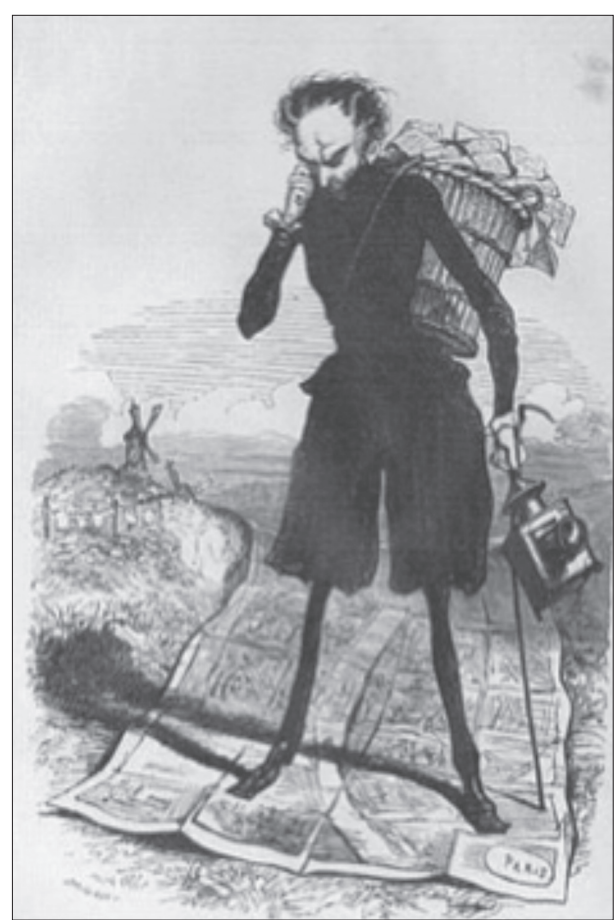

Imagen 13. Gavarni (dibujo). (1845-6) Le diable à Paris (El diablo en París). monóculo. El dibujante quiere significar que, gracias al trabajo intelectual de los escritores y dibujantes costumbristas (simbolizados por Flammèche), la ciudad se convertirá en el objeto de representación de los artículos (los papeles del cesto) de la colección: es gigante ante el mapa de la ciudad y de la sociedad parisina, que puede observar 'panorámicamente'. El proyector de la linterna mágica permite explicar que la diversidad social será visualizada en la colección, de la misma manera que este dispositivo la muestra en sus sesiones, a través de las galerías de sus diapositivas. Lauster (2007, p. 212) también ha llegado a la misma conclusión: los papeles del cesto y la linterna mágica que lleva el Diablo en su mano izquierda remiten, respectivamente, a la condición verbal y visual de la colección. 
En la litografía, ejecutada por Henry Wallis, de la cubierta del Volumen IV de los Sketches by Seymour (1838) (Imagen 14), de Robert Seymour, también encontramos la linterna mágica. Entre todos los paratextos visuales que analizamos en este artículo es un caso excepcional, ya que ofrece el momento de la proyección de este dispositivo visual (un maestro de ceremonias pasa una serie de diapositivas), en lugar de la preparación de la sesión de linterna mágica (Los mexicanos pintados por sí mismos) o del simple transporte del artilugio proyector en una de las manos del eremita (París o el libro del ciento y uno) o del Diablo Cojuelo (El diablo en París). Además, al quedar impreso sobre el artefacto el título de la compilación, se establece la equiparación entre el sketch (el texto costumbrista, sea una escena o un artículo sobre un tipo social) y las imágenes de las diapositivas proyectadas por la linterna mágica. El hecho de la aparición, en los frontispicios de algunos proyectos editoriales, del aparato de proyección de este dispositivo óptico refuerza la hipótesis de la interpretación del lienzo, en el frontispicio de otras colecciones costumbristas, como receptáculo de las sesiones de linterna mágica.

La figura demoníaca también aparece en la portada general del Volumen I de Los españoles pintados por sí mismos (1843) (Imagen 15). Al ser un diablo pequeño, queda asociado con Asmodeo. De su

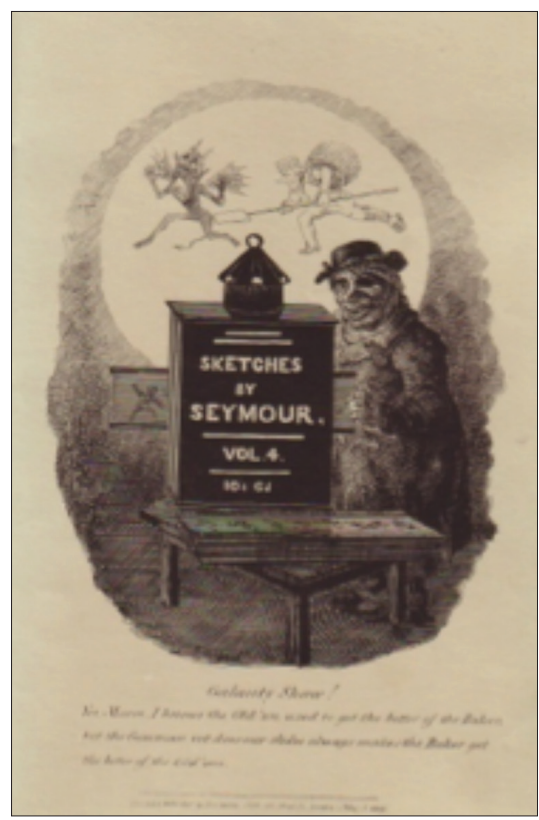

Imagen 14. Henry Wallis (Litografía). (1838). Sketches by Seymour, por Robert Seymour. Vol. IV.

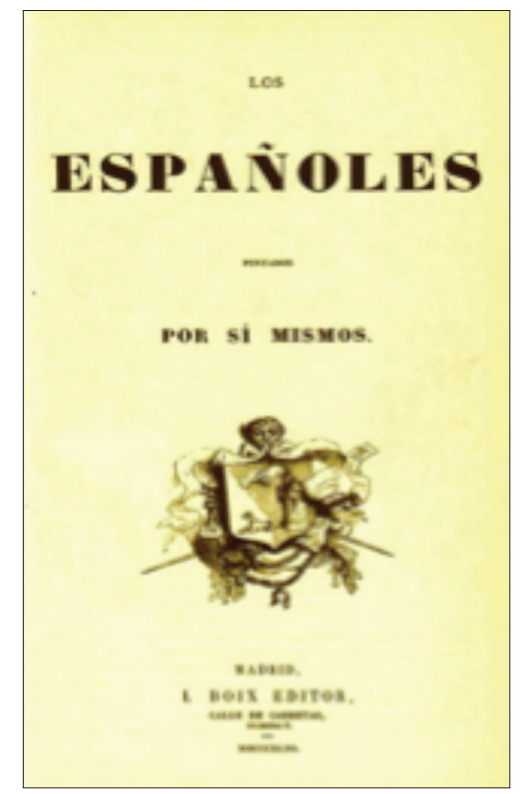

Imagen 15. Anónimo. (1843). Los españoles pintados por sí mismos. Vol. I. boca salen, a izquierda y a derecha, largos y ondulantes pliegos de papel que ribetean un escudo, situado delante de su pequeño cuerpo. Estos pliegos se pueden considerar, metafóricamente, como el conjunto de los artículos que integran la colección, producidos por el Diablo, por el espíritu satírico.

En el frontispicio de la otra gran colección de tipos sociales, Los cubanos pintados por sí mismos (1852) (Imagen 16), aparece representado un tutilimundi o cajón de vistas (en inglés, un peep-show) en lugar de una linterna mágica. La imagen representa una festividad pública al aire libre, en la que se integra este espectáculo. Un maestro de ceremonias pretende, con éxito, atraer la atención. Una persona mira a través del agujero practicado sobre uno de los lados del cajón de vistas. El espacio es tropical (se aprecian siete palmeras, un de ellas más próxima y las otras más lejanas). Un muchacho, impaciente por observar a través del agujero, pone la mano en el hombro del espectador que en estos momentos aplica su ojo al agujero del artefacto y parece decirle que ceda su turno. 


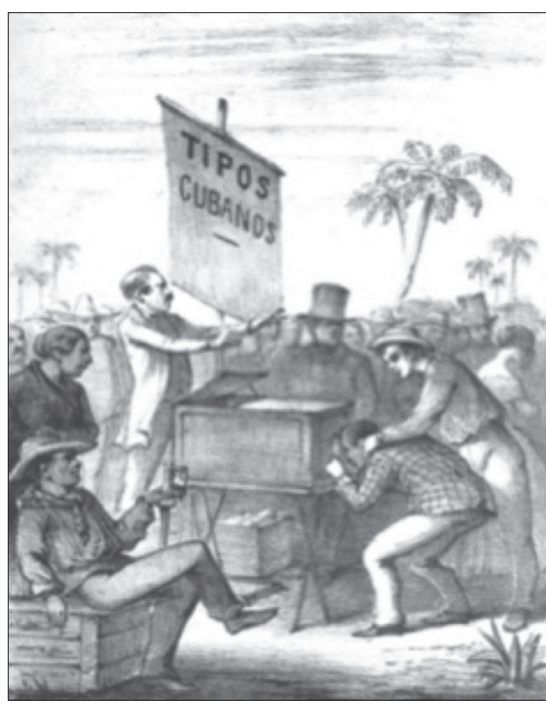

Imagen 16. Víctor Patricio de Landaluce (Dibujo) y José Robles (Grabado). (1852). Los cubanos pintados por sí mismos.
En la colección cubana, la incorporación del espectáculo óptico decimonónico, el tutilimundi, tiene también una intención metafórica, como en los casos analizados hasta ahora: se pretende afirmar que la colección de tipos sociales es panorámica, abarcadora, de la misma forma que el tutilimundi ofrecía la diversidad cultural de la sociedad mediante 'vistas' de los más importantes monumentos, paisajes y tipos humanos. Se reproduce en el frontispicio la situación típica de exhibición de este artefacto visual: la calle. Es un espectáculo popular, frente al menos difundido -en tierras hispanohablantes-, por más costoso, de la linterna mágica. ${ }^{12}$ Se trata de un frontispicio autorreflexivo, ya que aparece, metafóricamente, el acto de recepción de la colección: el público lector podrá apreciar una galería de retratos verbales e ilustrados de tipos sociales autóctonos semejantes a los que el cubano 've' por medio del tutilimundi.

\section{El afiche publicitario en Los franceses pintados por sí mismos}

Frente a los frontispicios alegóricos (diablos cojuelos que sostienen linternas mágicas) o que incentivan, además, de la lectura literal (la exhibición de las sesiones de linterna mágica ante un lienzo) un nuevo nivel de interpretación alegórica (alusión a las propias colecciones costumbristas), otros se anclan en un nivel de mayor literalidad. El público del frontispicio de Los franceses pintados por sí mismos (Volumen I) (Imagen 17) observa un afiche publicitario que promociona la suscripción y la lectura hacia este proyecto editorial. Esta literalidad no impide leer el frontispicio desde el discurso autorreflexivo: el sujeto que pega carteles representa a la empresa que promociona esta colección, mientras que el público alude tanto a los franceses que aparecerán representados en sus páginas como al conjunto de sus lectores. No es el único caso de presencia de afiches promocionales en las colecciones costumbristas, ya que también en el frontispicio del Tomo II de Los franceses pintados por sí mismos (Imagen 18) se observa en segundo plano un afiche publicitario de la colección, pegado sobre una pared, detrás de una figura demoníaca -sentada sobre libros canónicos de la literatura costumbristaque se dibuja a sí misma con la ayuda de un espejo de mano. Podemos concluir, por lo tanto, que el acto de promoción publicitaria del proyecto editorial -por lo menos para el caso de la colección francesa- es una situación prototípica, junto con la linterna mágica, la práctica pictórica y sus respectivos contextos de contextos de exhibición.

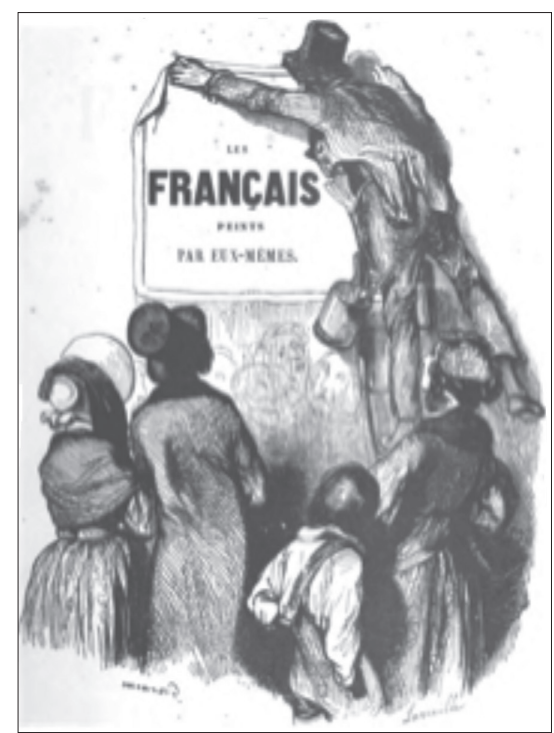

Imagen 17. Gavarni (Dibujo). (1840). Los franceses pintados por sí mismos. Vol I. 


\section{Conclusiones}

Los frontispicios de las colecciones costumbristas constituyen, ante sus lectores, la carta de presentación del libro. Sintetizan su contenido. Representan una modernización de los frontispicios del Clasicismo, donde el título del libro se encontraba asociado a la placa o lápida de una obra arquitectónica o artística, con el fin de destacar la condición de 'monumento impreso' del libro que el lector tenía entre sus manos.

Las imágenes de los frontispicios ilustran los objetivos de los proyectos editoriales desde la analogía con otras prácticas semióticas, todas ellas visuales: la pintura, el dibujo, la caricatura y los espectáculos ópticos. El propósito es legitimar estas colecciones desde la práctica prestigiosa del retrato pictórico o desde el poder de atracción de los espectáculos populares (linterna mágica, tutilimundi).

La incorporación de una escena donde aparecen figuras alegóricas que sostienen una 'linterna mágica'

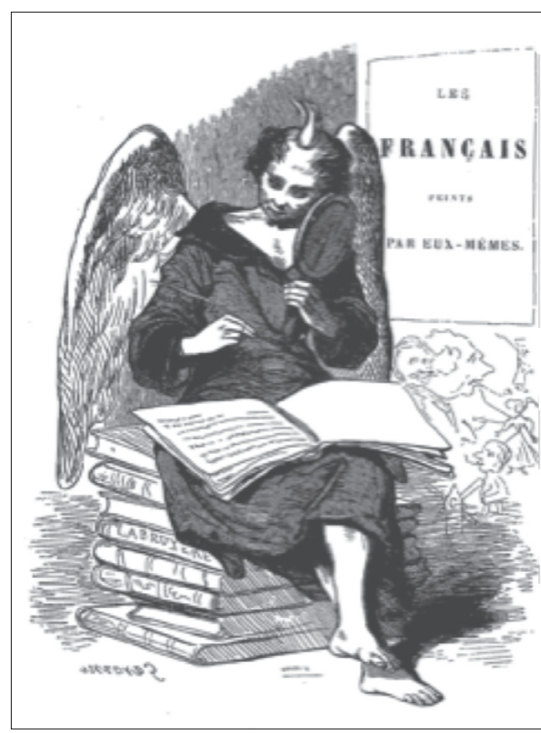

Imagen 18. Gavarni (Dibujo). Lavieille (Grabado en madera). (1840). Los franceses pintados por sí mismos. Vol. II. (en París o el libro del ciento y uno y El diablo en París), o de una escena donde se ofrece el contexto de exhibición de este dispositivo (el lienzo donde se proyecta en Los mexicanos pintados por sí mismos, Los belgas pintados por sí mismos y en el Volumen I de Los españoles pintados por sí mismos), así como la visualización del empleo del tutilimundi o peep-show (en Los cubanos pintados por sí mismos), tiene la intención metafórica de expresar que las colecciones costumbristas ofrecen una galería completa de tipos sociales, como hacían en aquel tiempo estos dispotivos ópticos populares.

En otros casos, se visualiza la analogía de la escritura costumbrista con la pintura (el Volumen II de Los españoles pintados por sí mismos, la viñeta del título de la edición de 1864 del Volumen II Heads of the people, el Volumen IV de Los franceses pintados por sí mismos). También se utilizan frontispicios metarreflexivos donde el dibujante aparece en el ejercicio de su desempeño (frontispicio del Volumen II de Heads of the people, frontispicio del Volumen III de Los franceses pintados por sí mismos).

Al recurrir a estas metáforas visuales, los proyectos editoriales de las colecciones quieren destacar que, además de constituir una práctica significante verbal, también lo es visual, y que ambas son equivalentes en sus funciones: la intención es tanto 'mostrar' (signo icónico) como describir (signo verbal) tipos sociales populares nacionales.

Vemos que se reproduce en los frontispicios de las colecciones, ya sean europeas o americanas, la situación típica de exhibición de los espectáculos ópticos y de la pintura de caballete: grupos de personas los consumen, en el papel de espectadores. Con ello se quieren promocionar como proyectos que atraen a la ciudadanía, en cuyas páginas, además, se verá esta última reconocida alrededor de la idea de Nación.

En este estudio comparativo, se ha comprobado la utilización de las mismas prácticas visuales, en su función analógica, en los frontispicios de los proyectos editoriales, procedan estos de Europa (Inglaterra, Francia, España) o Latinoamérica (Cuba o Mexico). El movimiento costumbrista, a escala internacional, no sólo utilizó los mismos tópicos en la descripción de los tipos sociales de los artículos, sino también motivos similares en la producción de sus frontispicios. 


\section{Notas}

1. En cambio, es un procedimiento que ha desaparecido de la práctica editorial actual, como se encarga de precisar Genette (2001, p. 33).

2. Aunque por lo general se interpreta que el movimiento romántico se produce un alejamiento de las analogías pictóricas, típicas del Clasicismo, a favor de la música, es cierto para la lírica (por su carácter expresivo). En cambio, en la corriente costumbrista permanecen vigentes las analogías pictóricas. Sin embargo, ya no se persigue un embellecimiento de la realidad, como en el caso del Clasicismo, sino una reproducción fiel de la realidad.

3. Son postales o estampas, muy populares antes de la llegada de las colecciones costumbristas, que representaban tipos sociales -en una hoja con su reproducción icónica, su identidad nominal y un pequeño texto-, tipos principalmente callejeros, dedicados a la venta ambulante, que llamaban la atención alzando la voz.

4. Preferimos utilizar el título en inglés, ya que carecen de sonoridad sus posibles traducciones al español: Cabezas de la gente, Bustos de la gente, Bustos humanos.

5. Es diferente lo que ocurre con las ilustraciones de inicial y final de la tabla de contenidos del Tomo I de Los franceses pintados por sí mismos, donde minúsculos tipos sociales se escapan de las manos del escritor y del dibujante (ilustración inicial) y son recogidos y colocados en un cesto (ilustración final) por Léon Curmer, el editor. Lauster (2007, p. 140) propone posiblemente sea una crítica de las pretensiones fáusticas asociadas a todo proceso creativo.

6. Se puede acceder a un análisis del proyecto mexicano en Pérez-Salas (2005, pp. 266-271).

7. Se puede apreciar en el catálogo de Mannoni y Campagnoni (2009, p. 41).

8. Ver catálogo de Mannoni y Campagnoni (2009, p. 40).

9. Ver catálogo de Mannoni y Campagnoni (2009, p. 54).

10. Ver catálogo de Mannoni y Campagnoni (2009, p. 12).

11. Por lo demás, recordemos que la linterna mágica, aunque se trata de un espectáculo nocturno proyectado en el interior de los edificios, la oscuridad de las noches cerradas también permitía la realización de espectáculos al aire libre.

12. La presencia del tutilimundi ha sido escasamente analizada en la cultura latinoamericana. Una excepción procede de Cuvardic (2012), quién ha estudiado el artículo costumbrista El panorama, del salvadoreño Arturo Ambrogi. A pesar de su nombre, no describe la llegada de un panorama a un pueblo salvadoreño, sino de una habitación de vistas en la que se encuentran ubicados diversos tutilimundis.

\section{Bibliografía}

Aguirre, M.B. (1841). Los niños pintados por ellos mismos. Obra arreglada al español por don Manuel Benito Aguirre. Madrid: Ignacio Boix.

Boix, I. (Ed.). (1843). Los españoles pintados por sí mismos. (Vol 1-2). Madrid: Autor.

Cuvardic-García, D. (2012). "Los espectáculos ópticos de la cultura popular salvadoreña: el tutilimundi en el artículo costumbrista El panorama, de Arturo Ambrogi”. Revista Káñina. 36 (1), 45-54.

Flores, A. (1846). Doce españoles de brocha gorda, que no pudiéndose pintar a sí mismos, me han encargado a mí, Antonio Flores, sus retratos. Novela de costumbres contemporáneas. Madrid: Imprenta de don Julián Saavedra y Compañía.

Gavarni, P. et ál. (1840). Les français peints par eux-mêmes. Encyclopédie morales du dixneuvième siècle. (Vol. I-IV). Paris: L. Curmier Éditeur. 
Genette, G. (2001). Umbrales. México: Fondo de Cultura Económica.

Janin, J. et ál. (1831-1834). Paris, ou Le Livre des Cent-et-un. (Vol. I-XV). Paris: Ladvocat.

Jerrold, D. et ál. (1840). Heads of the people; or Portraits of the English. With Original Essays by Distinguished Writers. [Ilustrado por Kenny Meadows]. London: Tyas.

Jerrold, D. et ál. (1864). Heads of the people; or Portraits of the English. With Original Essays by Distinguished Writers. [Ilustrado por Kenny Meadows]. Henry G. Bohn.

Lauster, Martina. (2007). Sketches of the Nineteenth Century. European Journalism and its Physiologies, 1830-50. Houndmills: Palgrave MacMillan.

Le Men, S. et Abélès, L. (Eds.). (1993). Les Français peints par eux-mêmes. Panorama social du XIXe siècle, catalogue de l'exposition au Musée d'Orsay du 23 mars au 13 juin 1993, Avec la participation de Nathalie Preiss-Basset, Paris, Réunion des musées nationaux. (4-46).

Mannoni, L. y Pesenti-Campagnoni, D. (2009). Lanterne magique et film peint. 400 ans de cinéma. Paris: Éditions de La Martinière.

Millán, J.A. (Ed.) (1852). Los cubanos pintados por sí mismos: colección de tipos cubanos. [Ilustrado por Lanzaluce]. [Grabados de José Robles). La Habana, Cuba: Imprenta y Papelería de Barcina.

Panofski, E. (1983). Iconografía e iconología. En: El significado en las artes visuales. (45-58). Madrid: Alianza Editorial.

Peñas-Ruiz, A. (2012). Aproximación a la literatura panorámica española (1830-1850). Interférences littéraires/Literaire interferenties. (8), 77-108.

Pérez-Salas, M.E. (2005). Costumbrismo y litografía en México: un nuevo modo de ver. México: Universidad Nacional Autónoma de México. Instituto de Investigaciones Estéticas.

Saillet, A. de. (1841). Les enfants peints par eux-mêmes. Paris: Desesserts éditeur.

Sand, G. et ál. (1845-1846). Le Diable à Paris. Paris et les Parisiens. Moeurs et coutumes, caracteres et portraits des habitants de Paris, tableau complet de leur vie privée, publique, politique, artistique, littéraire, industrielle, etc., etc. (Vol. I-II). Paris: Hetzel.

Segre, E. (2007). Intersected Identities. Strategies of Visualization in Nineteenth and Twentieth-century Mexican Culture. New York: Berhahn Books.

Seymour, R. (1838). Sketches by Seymour. (Vol. IV). Londres: G.S.Tregear.

Wechsler, J. (1982). A Human Comedy: Physiognomy and caricature in $19^{\text {th }}$ century Paris (Foreword by Richard Sennet). London: Thames and Hudson.

Ucelay Da Cal, M. (1951). Los españoles pintados por sí mismos (1843-44). Estudio de un género costumbrista. México: Colegio de México.

\section{Bibliografía de imágenes}

Imagen 1. Alenza, L. (Dibujo). Ortega, C. (Grabado). (1844). Frontispicio de Los españoles pintados por sí mismos. (Vol. II). Madrid: Ignacio Boix.

Imagen 2. Pauquet (Dibujo). Firma ilegible (Grabado). (1840). Frontispicio de Los franceses pintados por sí mismos. (Vol. IV). París: Léon Curmer. 
Imagen 3. Meadows, K (Dibujo). (1840). Frontispicio de Heads of the People. (Vol. I). London: Tyas.

Imagen 4. Pauquet (Dibujo), Guillaumot (Grabado). (1840). Frontispicio de Los franceses pintados por sí mismos. (Vol. III). París: Léon Curmer.

Imagen 5. Meadows, K. (Dibujo). (1864). Frontispicio de Heads of the People. (Vol I). London: Tyas.

Imagen 6. Meadows, K. (Dibujo). (1864). Viñeta de la página del título de Heads of the People. (Vol 2). London: Tyas.

Imagen 7. Miranda, F. de (Dibujo). Castilla A.G. (Grabado). (1846). Frontispicio de Doce españoles de brocha gorda. Madrid: Imprenta de don Julián Saavedra y Compañía.

Imagen 8. (Anónimo). (1841). Frontispicio de Los niños pintados por ellos [sic] mismos. Madrid: Ignacio Boix.

Imagen 9. Lameyer y Beranguer (Dibujo). (1843). Frontispicio de Los españoles pintados por sí mismos. (Vol. I). Madrid: Ignacio Boix.

Imagen 10. Dibujante anónimo (Litografía). (1935 [1854]). Frontispicio de Los mexicanos pintados por sí mismos. México: Biblioteca Nacional y Estudios Neolitho.

Imagen 11. Dillens, A. (Dibujo). Brown (Grabado). (1993 [1839-1840]). Frontispicio de "La fille du fabrique", de Les belges peint par eux-mêmes. Por S. Le Men (Ed.). Les Français peints par eux-mêmes. Panorama social du XIXe siècle. Paris, Réunion des musées nationaux.

Imagen 12. Monnier, H. (Dibujo); Thompson, C. (Grabado). (1831). Ilustración de la página del título de Paris, ou Le Livre des Cents-et-un (Vol. I). Paris: Ladvocat.

Imagen 13. Gavarni (Dibujo). (1845-1846). Frontispicio de Le diable à Paris (El diablo en París). Paris: Hetzel.

Imagen 14. Wallis, H. (Litografía). (1838). Ilustración de cubierta de Sketches by Seymour. (Vol. IV). Londres: G.S.Tregear. http://john-adcock.blogspot.com/ [Consulta: 17 de enero de 2013].

Imagen 15. Anónimo. (1843). Viñeta del título de Los españoles pintados por sí mismos. (Vol. I). Madrid: Boix Editor.

Imagen 16. Landaluce, V. P. de (Dibujo) y Robles, J. (Grabado). (1852). Frontispicio de la colección costumbrista Los cubanos pintados por sí mismos. La Habana: Imprenta y papelería de Barcina.

Imagen 17. Gavarni (Dibujo). (1840). Frontispicio de Los franceses pintados por sí mismos. (Vol. I). Paris: León Curmer.

Imagen 18. Gavarni (Dibujo). Lavieille (Grabado en madera). (1840). Frontispicio de Los franceses pintados por sí mismos. (Vol. II). Paris: León Curmer. 